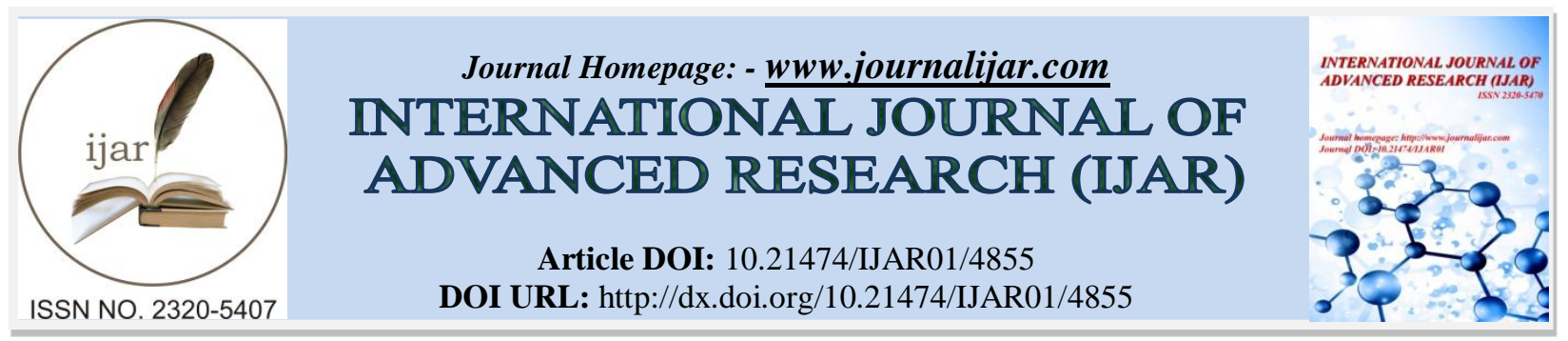

RESEARCH ARTICLE

\title{
BUILDING ORGANIZATIONAL PERFORMANCE: ANALYSIS OF TRANSFORMATIONAL LEADERSHIP STYLE AND SERVANT LEADERSHIP STYLE ON ORGANIZATION LEARNING IN DKI JAKARTA GOVERNMENT.
}

Djoko Setyo Widodo and P. Eddy Sanusi Silitonga.

Lecturer of Economic Faculty, Krisnadwipayana University, Jakarta Indonesia.

\section{Manuscript Info}

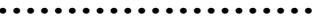

Manuscript History

Received: 15 May 2017

Final Accepted: 17 June 2017

Published: July 2017

Key words:-

Transformational Leadership Style, Servant Leadership Style, Organizational

Learning and Organizational

Performance.

\section{Abstract}

This study aims to analyze the influence of transformational leadership style and servant leadership style of service to organizational learning and organizational performance either partially or simultaneously on the government of DKI Jakarta. Population in this research is Head of Department and Head of Agency along with all Head of Division on all Work Unit of Regional Area of Jakarta Provincial Government amounting to163 people. Sampling method is done by census technique. Quantitative analysis method using path analysis, followed by determination analysis ( $\mathrm{R}$ Square), partial hypothesis testing ( $\mathrm{t}$ test) and simultaneous ( $\mathrm{F}$ test) with alpha 5 percent $(0,05)$. Prior to further analysis, the requirements analysis test is performed. Analytical tool using SPSS version 21.0 for windows. The result of the research shows that the transformational leadership style and servant leadership style of service are partially and simultaneously have positive and significant effect on organizational learning and organizational performance, as well as organizational learning has an influence on organizational performance in DKI Jakarta Government.

Copy Right, IJAR, 2017,. All rights reserved.

\section{Introduction:-}

The current development shows that the performance of the Government in DKI Jakarta Province has become the center of public attention, especially the performance of employees in terms of public services. Media both print and electronic always observe the activities of the Government in the Province of DKI Jakarta, especially today Governor in DKI Province has different characters and styles to solve the problem that is in way and approach different from the previous governor/leader.

Leaders have a very strategic role as one of the determinants of the success of an organization. To realize the achievement of public organization that is service to society hence required a reliable leader that able to bring organization in achieving vision, mission and aim of organization (Fauzan, 2010).

Some theory studies on leadership are still related to organizational performance (Timothy et al., 2011). Leadership is the whole activity / activity affect the willingness of others to achieve common goals (Siagian, 1986: 56). By improving the quality of human resources it is expected that the organization can maintain its survival and improve organizational performance (Winarno, 2012). 
Many researchers understand the impact of leadership on organizational performance and even many experts claim that leadership is one of the key driving forces to improve organizational performance (Timothy et al., 2011). Effective leadership is a good source of potential for organizational management development to gain competitive advantage and improve organizational performance (Rowe, 2001). Therefore, leadership is still an interesting topic to study and emulate. Implementation of leadership is most often observed but a phenomenon that is little understood by academics. The phenomenon of leadership style in Indonesia becomes an interesting problem to be studied in depth because it has a big influence in politics and state life. In business and public organizations, leadership styles still have a strong effect on the survival of the organization. The role of leadership is very strategic in an organization and as one of the determinants of success for achieving the vision, mission and goals of the organization.

Gibson (2009) states that one organizational factor such as leadership has an influence on organizational performance. It is also said by Timothy et al. (2011) who conducted a meta-analysis of leadership studies said that leadership style is still closely related to organizational goals of performance and also stated that leadership is one of the key strengths to improve organizational performance. More specifically, Avolio and Yammarino (2002) explain that transformational leadership still has an important role to play in improving performance. Similarly, Kaplan (2000) and Patterson (2003) explain that the style of servant leadership is an act of helping others sincerely to produce performance within the organization.

The results of Correa et al. (2005) indicates that there is a positive influence between organizational learning on organizational performance in large corporations in Spain. Correa et al. (2005) also explained that learning organizations are needed when organizations need the participation and activities of individuals / employees to improve performance. While the level of participation and individual activities can be obtained when there are leaders who have good capacity in the lead. The results of Correa et al. (2005) provide clues that there is a positive relationship between leadership style and organizational learning and organizational performance.

The results of theory-style leadership search found Mirkamali (2011) research that examined an automotive company in Iran. The results show that transformational leadership style can strengthen organizational learning for company employees. Reinforced by Nazem and Pileroud (2014) research which examined in several universities in Iran with the result of research that is influence of leadership style that is transformational towards organizational learning. Result of research provide the theoretical basis that transformational leadership has an influence on organizational learning.

Mittal (2012) examines the style of servant leadership in various cross-cultures in Asia and Europe. The results prove that servant leadership is an effective leadership. Mirkamali (2011) examines the effect of the transformational leadership style on organizational learning. Associated with the results of these studies, He suggested to future researchers to examine Organizational Learning related to other leadership style issues. During this time, the linking results between servant leadership style and organizational learning have never been found. Therefore, testing the leadership style of servants on organizational learning is a novelty in this study.

Based on the background and problems, the objectives of this research are:

1. Analyzing the influence of transformational leadership style and servant leadership style on partial and simultaneous organizational learning.

2. Analyze the influence of transformational leadership style, servant leadership style and organizational learning on partial and simultaneous organizational performance.

\section{Literature Review:-}

\section{Transformational Leadership Style:-}

The transformational leadership style is a leadership style used by a leader when a group stretches a boundary and performs beyond the status quo or achieves an entirely new set of organizational goals. Transformational leadership in principle motivates subordinates to do better than what can be done (Sashkin, 2011:24) in other words there is an increase in confidence or subordinate self-confidence that will affect the improvement of organizational performance.

In transformational leadership, not only change the structure and organizational process. But in a transformational leadership the leader transforms and develops people. Based on this, this study tends to use transformational 
leadership styles to identify changes in the leadership style of government institutions in Indonesia. Transformational leadership is applied because it is capable of transforming individuals, including leaders to become better (Sashkin, 2011: 12)

Transformational Leadership is leadership develop confidence followers to achieve the organization's mission (Avolio and Yammarino 2002). Transformational Leadership lies in the leader's ability to inspire the trust, loyalty, and pride of followers who subordinate their respective interests to the benefit of the group (Zagorsek, 2009).

Further Bass (2006: 123) Transformational leadership is defined as: the ability of the leader to change the working abilities, motivation, and work patterns, and the values of work perceived subordinates so used to optimize performance in achieving organizational goals.

Comez (2013) says that the behavior of transformational leadership is found to affect more positive performance. Particularly in a dynamic environment, visionary and highly charismatic leaders play an important role in the success of an organization. Transformational leadership is the last warm approach discussed over the past two decades. According to Luthan (2002) says that transformational leadership is included in modern leadership theory which was originally developed by Burns (1978: 128), which explicitly raises a theory that transformational leadership is: a process where the chief and his subordinates tried to reach The level of morality and motivation higher.

From the above opinion it is concluded that transformational leaders are measured by the level of trust, obedience, admiration, loyalty and respect of followers. The behaviors raised by transformational leadership can be drawn by some characteristics that characterize transformational leadership, among others:

1. Having a great vision and believing in intuition;

2. Placing itself as a motor of change;

3. Dare to take risks with careful consideration;

4. Giving awareness to subordinates of the importance of the work;

5. Having confidence in the ability of subordinates;

6. Flexible and open to new experiences;

7. Seeks to increase motivation higher than mere material motivation;

8. Encourage subordinates to place the interests of the organization above personal or group interests;

9. Able to articulate core values (culture/tradition) to guide the behavior of organizational members (Setiawan and Muhith, 2013: 26).

Some studies that discuss leadership styles related to organizational performance generally focus more on transformational leadership styles (Chodhary, 2012). Some research on transformational leadership uses factors of charisma, vision, motivational inspiration, intellectual stimulation, individual considerations. In line with Sashkin's (2011: 125) research, identifying transformational leadership variables is challenging processes, inspiring shared visions, enabling others to act, setting an example and being courageous.

\section{Servant Leadership Style:-}

The concept of servant leadership has actually been applied by world leaders long ago. Servant Leadership is a concept of ethical leadership introduced by Greenleaf since 1970. In a book entitled Servant Leadership, Greenleaf (1977: 121) mentions that the Leadership of servants is: leadership begins with sincere feelings that arise from the heart that Desires to serve, which is to be the first to serve. The choice that comes from the conscience then presents the desire to become a leader. The difference in manifestation in the service provided, first is to ensure that the needs of others can be met, ie to make the members of the organization mature, healthy, free and autonomous, so that they can become the next servant leader.

According to Poly (2011: 258) defines servant leadership as a process of mutual relations between leaders and those led in which the lead process first appears as a party serving the needs of the led members which causes the leader to be recognized and accepted as a leader.

Further Aurora (2009: 9), explains the servant leader is a person with a high sense of humanity. It is not the fate of the leader to be served, but it is a privilege to serve. There must be some element or understanding of life in high- 
quality leadership because without the character of this servant leader, leadership can seem to be and in fact be motivated to self-serve and self-interested.

In the leadership theory of servants initiated by Patterson (2003) there are seven characteristics that must be possessed by a servant leader, namely: 1) Agape love; 2) Humble; 3) Altruism; 4) Have a vision; 5) Trust; 6) Empowering other parties; And 7) Serving.

Meanwhile, according to Greenleaf (2003) there are ten characteristics of servant leadership are: 1) listening; 2) empathy; 3) solve the problem; 4) awareness; 5) persuasive; 6) conceptual; 7) vision; 8) Stewardship; 9) commitment to individual development; And 10) team building.

The following is the Servant Leadership indicator proposed by Dennis and Bocarnea (2005) which consists of:

1. Love. Leadership that loves with love or affection. Love is to do the right thing at the right time for the best reasons and decisions

2. Empowerment. The emphasis on cooperation is to give authority to others, and listen to the advice of the person being led.

3. Vision. The direction of the organization in the future to be carried by a leader, Vision will inspire action and help shape the future.

4. Humility. Maintain humility by showing respect for employees and recognizing employees' contribution to the team.

5. Trust. Servant-leader is the chosen people based on an advantage that leads the leader to gain trust.

\section{Organizational Learning:-}

Organizational learning is a process whereby individuals gain new knowledge and insights to change the behavior and actions of organizational members. Thus, organizational learning means the process of improving action through better knowledge and understanding (Fiol and Lyles, 1985). Kloot (1997) says that organizational learning is one of the process of identifying problems, the process of determining the best solution, and how the company can quickly respond to changes in the business environment that will affect the improvement of company performance.

Lopez et al. (2005) states that organizational learning is a dynamic process in creating, taking, and integrating knowledge to develop resources and capabilities in contributing to better organizational performance). In addition, organizational learning according to Robbins (2011: 112) states Organizational learning is: a process development is ongoing improved performance ability to face the challenges of individuals within the organization.

While Ellitan and Anatan (2009: 142) states that organizational learning occurs through the sharing of insights, knowledge and mental models built on knowledge and experience of the past. Fiol and Lyles (1985) defined organizational learning as "a process of improvement through knowledge and a better understanding."

Watkins and Marsick (2003) use 7 dimensions to measure Organizational Learning, namely:

1. Continuous Learning. The learning is designed into work so that people can learn on the job opportunities provided for education and sustainable growth.

2. Dialogue and Inquiry. Associated with the effort in creating an appropriate environment that makes individuals much more open minded, the organizational learning now creates an environment where knowledge experiences are learned through dialogue and interaction day by day.

3. Team Learning. Work is designed using groups to access the ways of thinking that are expected to learn together and work together in culturally valued and valued collaborations.

4. Embedded Systems. Both high and low technology systems for sharing learning are created and integrated with the access work provided for the system being maintained.

5. Empowerment. Indicates the organizational process for creating and sharing collective vision and getting feedback from members about the gap between the current status and the new vision.

6. System Connection. The members of the organization help to see the effect of the work done on the whole part of the company.

7. Provide Leadership. Model leader, champion, and learning support. Leadership uses strategic learning for business outcomes. 
In this study organizational learning variables are measured by three indicators from Yashoglu et al. (2014) consisting of internal practice, shared vision and main process.

\section{Organizational Performance:-}

Robbin (2011) describes performance as a measure of a result. Performance measurement is absolutely necessary to match the goals and targets to be achieved. Through the measurement also will be calculated the level of effectiveness and efficiency. However, performance has a broader meaning, not just the work, but includes how the work process takes place. While Performance according to Mangkunegara (2009) is the result of work in quality and quantity achieved by an employee in performing tasks in accordance with the responsibilities given.

According Wibowo (2011), performance has a broader meaning, not just the work, but including how the work process takes place. The goal of performance is to adjust individual performance expectations to organizational goals. Compliance between efforts to achieve individual goals with organizational goals will be able to realize good performance.

According Garvin (2008) Organizational performance is directed at the current condition of an organization to find out how far the organization has been at the level of effective and efficient. Therefore, when an organization performs a performance measurement, it should prioritize the relevance of performance measures with an organizational strategy, focus on output and verifiable.

Pasolong (2013: 178) describes several indicators used to measure the performance of public bureaucracy, namely:

1. Productivity, ie not only measures efficiency levels, but also measures the effectiveness of services. Productivity is generally understood as the ratio between input and output.

2. Quality of Service, many negative views are formed about public organizations that arise because of public dissatisfaction with quality. Thus, people's satisfaction with service can be an indicator of public bureaucracy performance.

3. Responsiveness, namely the ability of bureaucracy to recognize the needs of the community, set the agenda and priorities of service, and develop public service programs in accordance with the needs and aspirations of the community. Responsiveness is intended as one of the performance indicators because responsiveness directly describes the ability of the public bureaucracy in carrying out missions and goals, especially to meet the needs of society.

4. Responsibility, which explains whether the implementation of public bureaucracy activities are carried out in accordance with the principles of proper administration with bureaucratic policies, both explicit and implicit.

5. Accountability, ie, indicates how much public bureaucratic policy and activity are subject to political officials elected by the people.

\section{Conceptual Framework:-}

Based on the problem formulation and literature review described in the previous chapter, the conceptual framework of the study refers to relevant theories and research. As a comprehensive overview of the interrelationships between variables used in the research model, the following is presented in the conceptual framework of the study. Where the framework of the study can be described in (figure 1) as follows: 


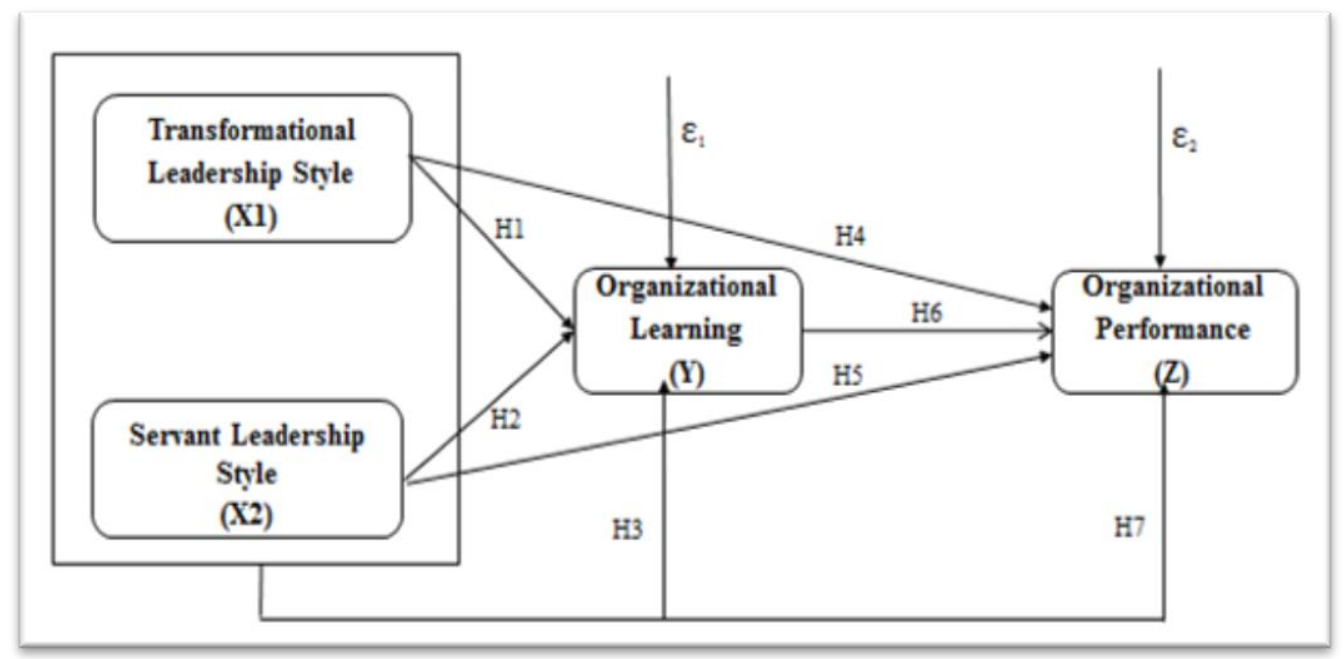

Figure 1:- Conceptual Framework

\section{Based on research objectives and theoretical reviews, the research hypothesis is:}

1. The transformational leadership style and servant leadership style influence the partial and simultaneous learning of the organization.

2. Transformational leadership style, servant leadership style and organizational learning affect the performance of the organization partially and simultaneously.

\section{Methods:-}

Approach in this research use quantitative approach with survey method and use path analysis technique. Path analysis is used to analyze patterns of relationships between variables with the aim to determine the direct or indirect effect of a set of independent variables (exogenous) to the dependent variable (endogenous).

Population in this research is Head of Department and Head of Agency along with all Head of Division on all Work Unit of Regional Area of Jakarta Provincial Government amounting to163 people. Sampling method is done by census technique.

Based on the purpose of research, the type of research used is explanatory research (explanatory research). Explanatory research is a research conducted to explain the causal relationship between research variables through hypothesis testing (Singarimbun and Effendi, 2012). The research approach used in this research is quantitative approach. The quantitative approach begins with theory, which is derived into a research hypothesis using deductive logic accompanied by measurement and operationalization of variables. Furthermore, generalization based on the results of statistical data so that it can be taken conclusion as research findings to answer the problems being faced.

Before the analysis, tested the questionnaire instrument with validity and reliability test, and normality test to test whether in the regression model, the dependent variable and free have normal distribution or not. Normality assumption is a very important requirement on significance test (significance) regression coefficient. A good regression model is a regression model that has a normal or near-normal distribution, so it is feasible to do statistical testing.

This research uses path analysis. This analysis is an option in order to study the dependence of a number of variables within the model. This analysis is a good method to explain if there is a large set of data to analyze and look for causal relationships. Path analysis is one of the analytical tools developed by (Dillon and Goldstein in Ali Hapzi and Limakrisna, N, 2013). Wright developed a method for knowing the direct and indirect effects of a variable, in which there are exogenous variables and endogenous variables. 
The path diagram consists of two substructures with two equations, where $X_{1}$ and $X_{2}$ are exogenous variables variable with no explicit cause, this variable serves as the independent variable/cause of the next sequence variable $\mathrm{Y}$ and $\mathrm{Z}$ as the endogenous variable.

\section{Result and Discussion:-}

In general, respondents gave a good perception of the questionnaires distributed in the Government of DKI Jakarta responded agree and strongly agree on the items of the questionnaire. This suggests that the transformational leadership style and servant leadership style have been applied in the DKI Jakarta Government. Organizational learning and organizational performance have also proceeded according to respondents' perceptions.

\section{Normality Test Results:-}

Before stepping into hypothesis testing, first tested normality. The test is done by using SPSS 21.0 as a tool in this research, it is found that the data in this study is normally distributed, it is proved from the result of significance value (asymp sig. 2-tailed) greater than 0.05, (0.339>0.05) so it can be concluded that the data in this study is normally distributed.

\section{Path Analysis:-}

This analysis is an option in order to study the dependence of a number of variables within the model. This analysis is a good method to explain if there is a large set of data to analyze and look for causal relationships.

To answer the objectives in this study, the main structure in the research model was broken into two sub-structures. Where to answer objective 1 (one) with the first sub-structure, and to answer goal 2 (two) by using the second substructure.

The output of the first structure equation in this research using SPSS 21.0 software as follows.

Table 1:- Coefficients regression.

\begin{tabular}{|c|c|c|c|c|c|c|}
\hline & & Coeffici & & & & \\
\hline & & $\begin{array}{r}\text { Unst } \\
\mathrm{Co} \\
\end{array}$ & $\begin{array}{l}\text { lardized } \\
\text { cients }\end{array}$ & $\begin{array}{c}\text { Standardized } \\
\text { Coefficients }\end{array}$ & $\mathrm{t}$ & Sig. \\
\hline & & $\mathrm{B}$ & Std. Error & Beta & & \\
\hline 1 & (Constant) & 3.968 & .869 & & 4.567 & .000 \\
\hline & X1_Transformational_Leadership_Style & .230 & .048 & 341 & 4.826 & .000 \\
\hline & X2_Servant_Leadership_Style & .225 & .042 & .377 & 5.346 & .000 \\
\hline
\end{tabular}

Source: Output SPSS under 21.0 for windows

Statistically the output of the above coefficients table obtained the following equation.

$$
\mathbf{Y}=\mathbf{P y x}_{\mathbf{1}} . \mathbf{X}_{\mathbf{1}}+\mathbf{P y x}_{\mathbf{2}} . \mathbf{X}_{\mathbf{2}}+\mathbf{e}_{\mathbf{1}}
$$

$\mathrm{Y}=0,341 \cdot \mathrm{X}_{1}+0,377 \cdot \mathrm{X}_{2}+\mathrm{e}_{1}$ 
The result of the above equation is inserted into the picture of structural equation as below:

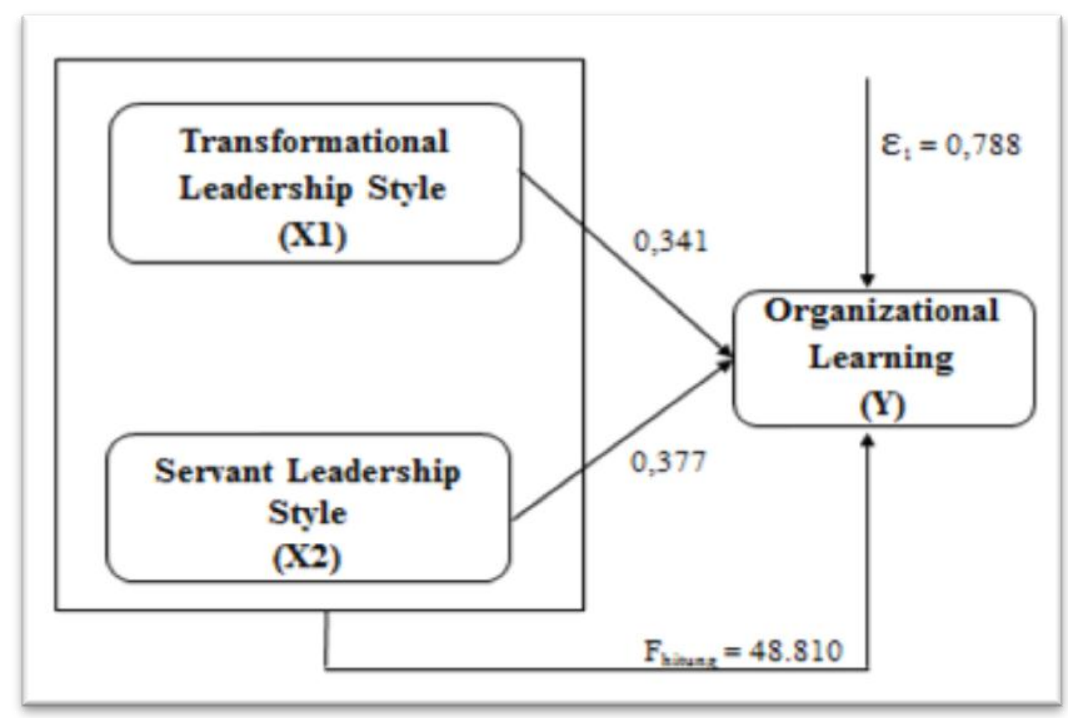

Figure 2:- Result of Sub Line Analysis of Structure I

To know the influence of transformational leadership style and servant leadership style partially on organizational learning, then tested by $\mathrm{t}$ test (Partial). The statistic $\mathrm{t}$ test basically shows how far the influence of an individual explanatory variable in explaining the dependent variation. This test is done by looking at the statistical value of $t$ calculation results then compare it with the value of $t$ table with the degree of confidence of $5 \%$. The following will be described one by one test partially in this study.

The Influence of Transformational Leadership Style to Organizational Learning:-

From result of output of SPSS as shown in Table 1, it is obtained that the value of $t$ count variable $X_{1}$ is 4,826 , with significance level 0.000 , because the level of significance is more $<0.05(0.000<0.05)$ it can be concluded that the transformational leadership style influence on learning organization. Based on the explanation $\mathrm{H}_{0}$ is therefore rejected and $\mathrm{H}_{1}$ accepted, meaning that the transformational leadership style affect the learning organization.

The results of this study are in line with research conducted by Mirkamali (2011) to prove that the transformational leadership style can strengthen organizational learning for company employees. Reinforced by Nazem and Pileroud (2014) research which examined in several universities in Iran with the result of research that is influence of leadership style that is transformational towards organizational learning. Result of research Mirkamali (2011); Nazem and Pileroud (2014) provide the theoretical basis that transformational leadership has an influence on organizational learning.

The Influence of Leadership Style of Servant to Organizational Learning:-

From the result of output of SPSS as seen in Table 1, it can be seen that the value of $t$ count variable $X_{2}$ is 5,346, with significance level of 0.000 , because the level of significance is more $<0.05(0.000<0.05)$ it can be concluded that the leadership style of waiter influence on learning organization. Based on the explanation $\mathrm{H}_{0}$ is therefore rejected and $\mathrm{H}_{1}$ accepted, meaning that the leadership style of the waiter effect the learning organization.

The results of this study are in line with research conducted by Mittal (2012) examining the style of servant leadership in various cross-cultures in Asia and Europe. The results prove that servant leadership is an effective leadership.

The Influence of Transformational Leadership Style and Leadership Style of Servant to Simultaneous Organizational Learning:-

In testing this hypothesis used Test $\mathrm{F}$ (simultaneous). $\mathrm{F}$ test is basically used to test the significant influence of some independent variables to dependent variable. In this case F Test is used to test significantly the effect of 
transformational leadership style and leadership style of minister jointly to organizational learning. The following is an output of SPSS 21.0 for the F (Simultaneous) test.

Table 2:- F test Results Simultaneously

\begin{tabular}{|l|l|r|r|r|r|r|}
\hline \multicolumn{7}{|c|}{ ANOVA $^{\text {a }}$} \\
\hline Model & Sum of Squares & Df & Mean Square & F & Sig. \\
\hline \multirow{5}{*}{1} & Regression & 172.248 & 2 & 86.124 & 48.810 & $.000^{\text {b }}$ \\
\cline { 2 - 7 } & Residual & 282.317 & 160 & 1.764 & & \\
\cline { 2 - 7 } & Total & 454.564 & 162 & & \\
\hline \multicolumn{2}{|l|}{ a. Dependent Variable: Y_Organizational_Learning } \\
\hline \multicolumn{2}{|l}{ b. Predictors: (Constant), X2_Servant_Leadership_Style, X1_Transformational_Leadership_Style } \\
\hline
\end{tabular}

From anova or F test using SPSS 21.0 obtained F count of 48.810 with p-value probability 0.000 , because the level of significance level is much more $<0.05(0.000<0.05)$ Therefore $\mathrm{H}_{0}$ is rejected and $\mathrm{H}_{1}$ accepted, so it can be concluded that the hypothesis Zero $\left(\mathrm{H}_{0}\right)$ is rejected and alternative hypothesis $\left(\mathrm{H}_{1}\right)$ is accepted meaning this proves the variables of transformational leadership style and servant leadership style together significantly influence to organizational learning variable.

The result of hypothesis statistic test can be concluded that the transformational leadership style, and the leadership style of the waiter have a significant effect on organizational learning. This shows that the application of transformational leadership style, and the appropriate servant leadership style in accordance with the condition of the organization will be able to create the right organizational learning organization, especially in DKI Jakarta Government.

This suggests that organizational learning contributed by internal indicators of practices, shared values and main processes, can be influenced by leadership styles. This means that to create a more conducive learning organization, the leadership style in DKI Jakarta Government needs to be considered, among others, transformational leadership style through challenging process, and leadership style of minister through sharing the vision among the organization members in DKI Jakarta Government.

To measure how far the ability of the model in explaining the variation of the dependent variable, can be seen from the coefficient of determination as follows.

Table 3:- Model summary

\begin{tabular}{|l|l|c|c|c|}
\hline \multicolumn{4}{|c|}{ Model Summary } \\
\hline Model & R & R Square & Adjusted R Square & Std. Error of the Estimate \\
\hline 1 & $.616^{\text {a }}$ & .379 & .371 & 1.328 \\
\hline \multicolumn{2}{|l|}{ a. Predictors: (Constant), X2_Servant_Leadership_Style, X1_Transformational_Leadership_Style } \\
\hline
\end{tabular}

A $R$ value of 0.616 shows a double correlation (transformational leadership style and servant leadership style) with organizational learning. Considering the variation of $\mathrm{R}$ Square Value of 0.379 , it has the meaning of the role or contribution of variable of transformational leadership style and the leadership style of the servant able to explain the organizational learning variable by $37.9 \%$. While the rest of $62.1 \%$ influenced by other variables that are not included in this model.

Where other variables or other factors that can affect the learning organization such as competence and motivation Employees. While the results of other studies explain that competence and work motivation have positive and significant impact on employee performance either partially or simultaneously (Aima, H., and Ali, Hapzi., et al., 2017). 
The output of the second structure equation in this study by using SPSS 21.0 software as follows.

Table 4:- Coefficients regression

\begin{tabular}{|c|c|c|c|c|c|c|}
\hline \multicolumn{7}{|c|}{ Coefficients $^{\mathrm{a}}$} \\
\hline \multirow{2}{*}{\multicolumn{2}{|c|}{ Model }} & \multicolumn{2}{|c|}{$\begin{array}{c}\text { Unstandardized } \\
\text { Coefficients }\end{array}$} & \multirow{2}{*}{$\begin{array}{c}\text { Standardized } \\
\text { Coefficients } \\
\text { Beta }\end{array}$} & \multirow[t]{2}{*}{$\mathrm{T}$} & \multirow[t]{2}{*}{ Sig. } \\
\hline & & $\mathrm{B}$ & Std. Error & & & \\
\hline \multirow[t]{4}{*}{1} & (Constant) & 6.804 & 1.322 & & 5.147 & .000 \\
\hline & X1_Transformational_Leadership_Style & .326 & .073 & .315 & 4.474 & .000 \\
\hline & X2_Servant_Leadership_Style & .219 & .066 & .239 & 3.348 & .001 \\
\hline & Y_Organizational_Learning & .419 & .113 & .273 & 3.704 & .000 \\
\hline
\end{tabular}

a. Dependent Variable: Z_Organizational_Performance

Source: Output SPSS under 21.0 for windows

Statistically the output of the above coefficients table obtained the following equation.

$$
\mathbf{Y}=\mathbf{P z x}_{1 .} \mathbf{X}_{1}+\mathbf{P z x}_{2 .} \mathbf{X}_{2}+\mathbf{P z y} . \mathbf{Y}+\mathbf{e}_{2}
$$

$\mathrm{Y}=0,315 \cdot \mathrm{X}_{1}+0,239 \cdot \mathrm{X}_{2}+0,273 \cdot \mathrm{Y}+\mathrm{e}_{2}$

The result of the above equation is inserted into the picture of structural equation as below:

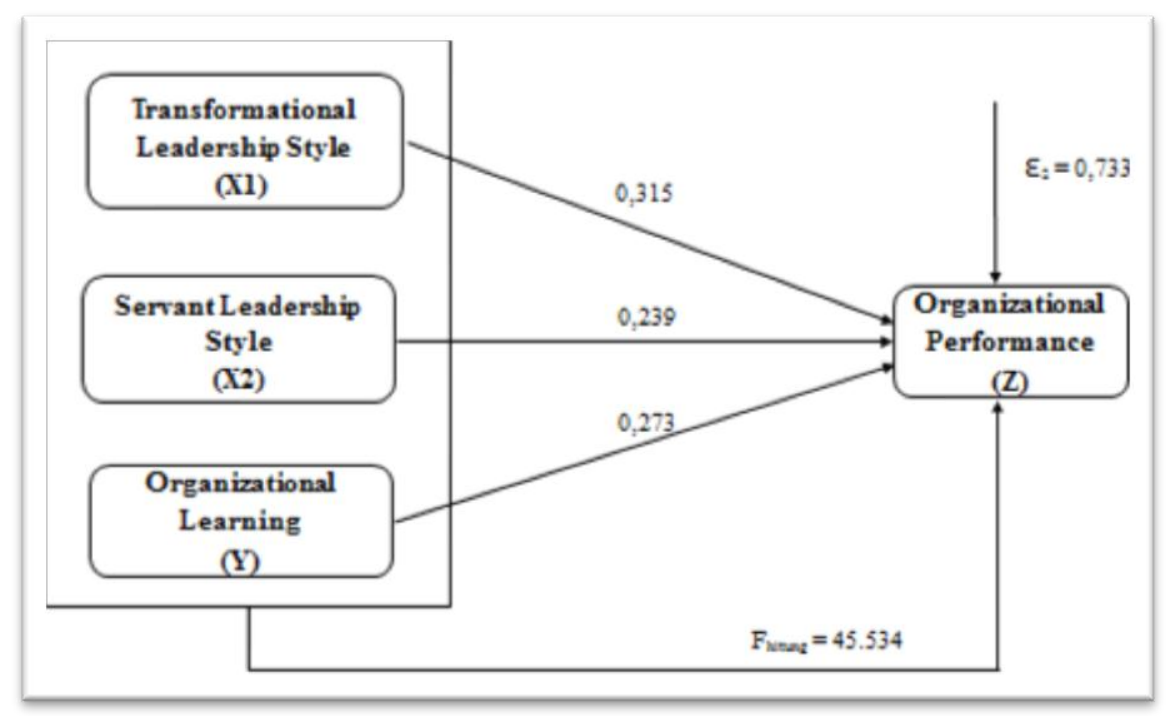

Figure 3:- Result of Sub Line Structure Analysis II

To know the influence of transformational leadership style, servant leadership style and organizational learning partially on organizational performance, then tested by t test (Partial). The following will be described one by one test partially in this study.

\section{The Influence of Transformational Leadership Style to Organizational Performance:-}

From result of output of SPSS as shown in Table 4 that got obtained value $t$ count value of variable $\mathrm{X}_{1}$ equal to 4,474 , with significance level equal to 0.000 , because level of significance level more $<0.05(0.000<0.05)$ hence can be concluded that transformational leadership style influence to performance organization. Based on the explanation $\mathrm{H}_{0}$ is therefore rejected and $\mathrm{H}_{1}$ accepted, meaning that transformational leadership style affect the performance of the organization. The results of this study can support the theory that suggests transformational leadership still has an important role to improve performance (Avolio and Yammarino, 2002).

The Influence of Servant Leadership Style to Organizational Performance:-

From result of output of SPSS as seen in Table 4 that got obtained value t count value of variable $\mathrm{X}_{2}$ equal to 3,348, with level of significance equal to 0,001 , because level of significance level more $<0.05(0.001<0.05)$ hence can be concluded that style of servant leadership influence to performance organization. Based on the explanation $\mathrm{H}_{0}$ is therefore rejected and $\mathrm{H}_{1}$ accepted, meaning that the leadership style of the waiter affect the performance of the 
organization. The results of this study can support a theory that explains that the style of servant leadership is an act of helping others sincerely to produce performance within the organization (Kaplan, 2000., and Patterson, 2003).

\section{The Influence of Organizational Learning on Organization Performance:-}

From the result of output of SPSS as seen in Table 4, it is found that the value of $\mathrm{t}$ count variable $\mathrm{Y}$ is 3,704, with significance level 0.000 , because the level of significance is more $<0.05(0.000<0.05)$ it can be concluded that organizational learning has an effect on organizational performance . Based on the explanation $\mathrm{H}_{0}$ is therefore rejected and $\mathrm{H}_{1}$ accepted, meaning that organizational learning affect the performance of the organization.

The results are in line with research conducted by Correa et al. (2005) indicates that there is a positive influence between organizational learning on organizational performance in large corporations in Spain. Correa et al. (2005) also explained that learning organizations are needed when organizations need the participation and activities of individuals/employees to improve performance.

The Influence of Transformational Leadership Style, Servant Leadership Style and Organizational Learning to Organization Performance Simultaneously:-

In testing this hypothesis used Test $\mathrm{F}$ (simultaneous). $\mathrm{F}$ test is basically used to test the significant influence of some independent variables to dependent variable. In this case F Test is used to test significantly the influence of transformational leadership style, leadership style of waiter and organizational learning together to the performance of organization. The following is an output of SPSS 21.0 for the F (Simultaneous) test.

Table 5:- F test results simultaneously

\begin{tabular}{|c|c|c|c|c|c|c|}
\hline \multicolumn{7}{|c|}{ ANOVA ${ }^{\mathrm{a}}$} \\
\hline & \multicolumn{5}{|c|}{\begin{tabular}{|l|l|l|l|l|l|} 
Model & Sum of Squares & Df & Mean Square & F & Sig. \\
1
\end{tabular}} \\
\hline \multirow[t]{3}{*}{1} & Regression & 493.493 & 3 & 164.498 & 45.534 & $.000^{\mathrm{b}}$ \\
\hline & Residual & 574.409 & 159 & 3.613 & & \\
\hline & Total & 1067.902 & 162 & & & \\
\hline \multicolumn{7}{|c|}{ a. Dependent Variable: Z_Organizational_Performance } \\
\hline \multicolumn{7}{|c|}{$\begin{array}{l}\text { b. Predictors: (Constant), Y_Organizational_Learning, X1_Transformational_Leadership_Style, } \\
\text { X2_Servant_Leadership_Style }\end{array}$} \\
\hline
\end{tabular}

From Anova or F test using SPSS 21.0 obtained F count of 45,534 with probability p-value equal to 0.000 , because the level of significance level is much more $<0.05(0.000<0.05)$ Therefore $\mathrm{H}_{0}$ is rejected and $\mathrm{H}_{1}$ accepted, so it can be concluded that the hypothesis Zero $\left(\mathrm{H}_{0}\right)$ is rejected and alternative hypothesis $\left(\mathrm{H}_{1}\right)$ is accepted meaning this proves the variable of transformational leadership style, servant leadership style and organizational learning together significantly influence to organizational performance.

The result of statistical test can be concluded that transformational leadership style, and waiter influence to organizational performance. This shows that the application of transformational leadership style, and the appropriate servant leadership style in accordance with the condition of the organization will improve the organization's performance in DKI Jakarta Government.

The findings of this study support the theory of Morales et al. (2012), Timothy (2011), Correa et al. (2007), Chuodhary (2012), which states that the transformational leadership style and leadership style of the waiter have a significant effect on the improvement of organizational performance. Several previous studies were conducted in private organizations and have not found results of research conducted in public organizations. It is also the novelty of this research that the transformational leadership style and servant leadership style is aptly applied to public organizations.

To measure how far the ability of the model in explaining the variation of the dependent variable, can be seen from the coefficient of determination as follows.

Table 6:- Model summary

\begin{tabular}{|c|c|c|c|c|}
\hline \multicolumn{5}{|c|}{ Model Summary } \\
\hline Model & $\mathrm{R}$ & R Square & Adjusted R Square & Std. Error of the Estimate \\
\hline 1 & $.680^{\mathrm{a}}$ & .462 & .452 & 1.901 \\
\hline
\end{tabular}


a. Predictors: (Constant), Y_Organizational_Learning, X1_Transformational_Leadership_Style, X2_Servant_Leadership_Style

The $\mathrm{R}$ value of 0.680 shows a double correlation (transformational leadership style, servant leadership style and organizational learning) with organizational performance. Considering the variation of R Square Value of 0.462, it has the meaning of the role or contribution of variables of transformational leadership style, leadership style of waiter and organizational learning able to explain organizational performance variable equal to $46,2 \%$. While the rest of 53.8\% influenced by other variables that are not included in this model.

Where other factors that can affect the performance of the organization include the Competence and Employee Motivation. Competence and Motivation Employees have positive and significant impact on Employee Performance, either partially or simultaneously (Aima, H., and Ali, Hapzi., et al., 2017). Besides, Job Motivation and Job Satisfaction have positive and significant influence on Organizational Commitment and impact on Employee Performance, (Masydzulhak and Ali, Hapzi., et al, 2016).

\section{Conclusion:-}

\section{Based on the results and discussion then the conclusion of this research Are:-}

1. Transformational leadership style with challenging Process dimension; Enabling others; Exemplary and Encouraging, and the style of servant leadership with a dimension of affection; Empowerment; Vision; Humility and trust affect the learning of the organization partially and simultaneously with the dimensions of Internal practices; Shared values and main processes. This means that the better the transformational leadership style and leadership style of service that is owned by a leader will be better also with organizational learning, and vice versa, in the Regional Government of DKI Jakarta Province.

2. Transformational leadership style with challenging Process dimension; Enabling others; Exemplary and Encouraging, the style of servant leadership with the dimension of affection; Empowerment; Vision; Humility and trust, and organizational learning with dimensions of Internal practices; Shared values and main processes influence the performance of the organization partially and simultaneously with the dimensions of productivity; Quality of service; Responsiveness; Responsibility and accountability. This means that the better the transformational leadership style, the leadership style of the waiter and the organization's learning will be better also with the performance of the organization, and vice versa, in the Regional Government of DKI Jakarta Province.

\section{Suggestion:-}

Based on data analysis, statistical calculation process, empirical research model test and discussion of the results of the study conducted, submitted some suggestions as follows:

1. Based on the results of empirical studies from the results of this study that the performance of organizations in the Government of DKI Jakarta can still be improved, by applying a transformational leadership style and leadership style of a good waiter to the organization that is by balancing between rewards and balanced sanctions, in order to better achievement. In addition, the implementation of organizational learning model with shared vision and good working relationships and build the values of the organization will be able to improve performance in the Government of DKI Jakarta.

2. The transformational leadership style is oriented towards the improvement of the working proficiency to be more precedent in order to improve the performance of the organization in carrying out the service to the more prime society. This is based on responses from respondents who give high value to indicators of transformational leadership style and servant leadership style.

3. Need to do research with a relatively larger sample involving organizations from other Governments that can be used as a comparison, so that generalization of research results can more represent the condition of Government in general in Indonesia.

4. It is necessary to consider other variables in shaping organizational performance in addition to indicators in transformational leadership styles, servant leadership styles and organizational learning. For example, organizational culture variables, organizational commitment in order to improve the performance of public organizations 


\section{References:-}

1. Aima, Havidz and Ali, Hapzi, et al., 2017. Model of Employee Performance: Competence Analysis and Motivation (Case Study at PT. Bank Bukopin, Tbk Center). Quest Journals Journal of Research in Business and Management, ISSN (Online) : 2347-3002. Volume $4 \sim$ Issue 11 (2017) pp: 49-59. www.questjournals.org

2. Aurora. 2009. Leadership Servant Leadership Model at Bogor Agricultural University. Faculty of Economics and Management Bogor Agricultural University

3. Avolio,B.J dan Yammarino,F.J. 2002. Transformational and charismatic leadership: The road ahead. Oxford. Elsevier Science. UK:

4. Bass, M. Bernard dan Riggio, E. Ronald. 2006. Transformational Leadership. Second Edition. New Jersey.

5. Burns, J. M. 1978. Leadership.New York: Harper \& Row.

6. Choudhary. 2012. Impact of Transformational and Servant Leadership on Organizational Performance: A Comparative Analysis. Journalof Business Ethics.Vol.8. pp 12-47

7. Correa,J.Albert Aragon, Victor J. Garcia-Morales dan Eulogio Cordon-Pozo. 2005. Leadership and organizational learning's role on innovation and perfomance: Lesson from Spain. Industrial Marketing Management. Vol 36. pp 349-359.

8. Dennis, R.S dan Bocarnea, M. 2005. Development of the servant leadership assesment instrument. Leadership and organization development journal. Vol.26. pp 600-615

9. Ellitan, Anatan and Anatan, Lina. 2009. Management of Innovation Transformation Toward a World Class Organization. Bandung: CV Alfabeta.

10. Fauzan, Muh. 2010. Effect of Leadership Style on Job Satisfaction and Performance with Organizational Commitment as Intervening Variable (Study at PT Yudhistira Ghalia Indonesia area Yogyakarta). Thesis. Diponegoro University. SemarangFiol, C.M dan M.A. Lyies.1985. Organizational Learning. Academy of Management Review. Vol. 10. No. 4. pp 803-813

11. Garvin. 2008. Power, mastery and organizational learning. Journal of management studies. Vol.37. pp $833-851$

12. Gibson, Ivan Cevich dan Donelly. 2009. Organizational Behavior Structure Processes. New York: McGraw-Hill /Irwin

13. Greenleaf,R.K. 1977. Servant Leadership: A journey into the nature of legimate power and greatness. LC. Spears. USA.

14. Hapzi, Ali., dan Limakrisna, N. (2013). Research Methodology. Edisi 1, Cet. 1, Deepublish, Yogyakarta.

15. Kaplan, S.2000. Human nature and Environmentally Responsible Behaviour.Journal of Social. Issue 56.p. 491.

16. Kloot, L. 1997. Organizational learning and management control systems: responding to environmental change. Management Accounting Research, 8(1): 47-73.

17. López, S. P., José, M. M. P., dan Ordás, C. J. V. 2005. Organizational learning as a determining factor in business performance. The learning organization, Vol.12 pp 25-46

18. Luthans, Fred. 2002. Organizational Behavior, Ninth Edition. Singapore: McGraw- Hill International Editions.

19. Mangkunegara. 2009. Evaluasi Kinerja Sumber Daya Manusia. Eresco. Jakarta.

20. Masydzulhak, Ali, Hapzi., \& Leni, 2016. The Influence of Work Motivation and Job Satisfaction on Employee Performance and Organizational Commitment as an Satisfaction as an Intervening Variable, in PT. Asian Isuzu Casting Center. Quest Journal of Research in Business and Management (QUESTJBM).ISSN (Online): 2347-3002.www.questjournals.org.Vol.4, Issue10, 2016, page[01-10].

21. Mirkamali, Seyyed Mohammad, Fatemeh Narenji Thami dan Farnoosh Alami, 2011. Examining the role of transformational leadership and job satisfaction in the organizational learning of an automotive manufacturing company. Social and Behaviour Sciences. Vol 29. pp 139-148

22. Nazem, Fattah dan Roghieh Nezhadi Pileroud.2014.Prediction of employee organizational learning based on the leadership styles (transformational and transactional) and social capital at Islamic azad university. Indian Journal of Fundamental and Applied Life Sciences.Vol. 4 (S4). pp. 3270-3276

23. Help. 2013. Bureaucratic Leadership. Bandung: CV Alfabeta. 
24. Patterson, K.A. 2003. Servant Leadership: A Theoritical Model. Dissertation. Universitas Muslim Indonesia. Macassar

25. Robbins, P. Stephen. 2011. Organizational Behavior, Concept, Controversy, Application Volume I. Jakarta: PT Prehall Prenhalindo.Rowe, W. G. 2001. Creating Wealth in Organizations: The Role of Strategic Leadership. Academy of Management Executive.Vol.15 pp 81-94.

26. Sashkin, Marshal dan Molly G. Sashkin. 2011. Leadership That Matters, Penterjemah Rudolf Hutauruk. Jakarta: Penerbit Erlangga.

27. Setiawan, Bahar Agus dan Muhith, Abd. 2013. Transformasional Leadership: Ilustrasi di Bidang Organisasi Pendidikan. Jakarta: Rajawali Pers.

28. Siagian.1986.Teori dan Praktek Kepemimpinan. Jakarta: Rineka Cipta.

29. Singarimbun, M \& Effendi, S. (2012). Metode Penelitian Survey. Jakarta: LP3ES.

30. Timothy, C. Obiwuru, Andi T. Okwu, Victoria O. Akpa, Idowu A. Nwakwere. 2011. Effect of leadership style on organizational performance: A survey of selected small scale enterprises in IkosiKetu council development area of Lagos State,Nigeria. AustralianJournal of Business and Management Research. Vol.1.pp 100-111

31. Watkins, K.E. And Marsick, V.J. 2003. Dimensions of the learning organization.Warwick, RI: Partners for the Learning Organization. Wibowo. (2011). Work management. Jakarta: PT. Raja Grafindo Parsada.

32. Winarno. 2012. The influence of human capital and organizational learning on organizational performance is mediated by organizational competence and innovation culture.Disertasi. Universitas Brawijaya Malang Yashoglu, M. Murat, Omer Sap dan Duygu Toplu. 2014. An investigation of the characteristics of organizationallearning in Turkish Companies: Scale Validation. Procedia-Social and Behavioral Sciences. No. 7150 pp. 726-734

33. Zagoršek. 2009. Transactional and transformational leadership impacts on organizational learning, Global Journal of Management and Business Research.Vol 21. pp 146-165. 